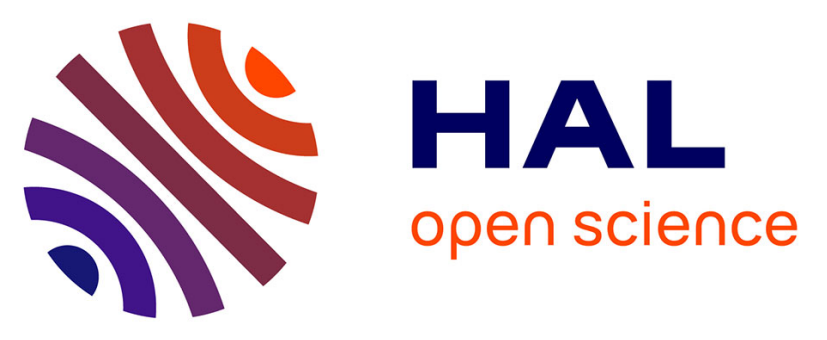

\title{
High-Dose Pegylated Interferon- $\alpha$ and Ribavirin in Nonresponder Hepatitis C Patients and Relationship With IL-28B Genotype (SYREN Trial).
}

Stéphane Chevaliez, Christophe Hézode, Alexandre Soulier, Bruno Costes, Magali Bouvier-Alias, Stéphanie Rouanet, Juliette Foucher, Jean-Pierre

Bronowicki, Albert Tran, Isabelle Rosa, et al.

\section{To cite this version:}

Stéphane Chevaliez, Christophe Hézode, Alexandre Soulier, Bruno Costes, Magali Bouvier-Alias, et al.. High-Dose Pegylated Interferon- $\alpha$ and Ribavirin in Nonresponder Hepatitis C Patients and Relationship With IL-28B Genotype (SYREN Trial): High-Dose peg-IFN and Ribavirin and IL28B in HCV nonresponders. Gastroenterology, 2011, 141 (1), pp.119-27. 10.1053/j.gastro.2011.03.039 . inserm-00611186

\section{HAL Id: inserm-00611186 https://www.hal.inserm.fr/inserm-00611186}

Submitted on 25 Jul 2011

HAL is a multi-disciplinary open access archive for the deposit and dissemination of scientific research documents, whether they are published or not. The documents may come from teaching and research institutions in France or abroad, or from public or private research centers.
L'archive ouverte pluridisciplinaire HAL, est destinée au dépôt et à la diffusion de documents scientifiques de niveau recherche, publiés ou non, émanant des établissements d'enseignement et de recherche français ou étrangers, des laboratoires publics ou privés. 


\title{
High-Dose Pegylated Interferon Alfa and Ribavirin in Non-responder
}

\section{Hepatitis C Patients and Relationship with IL28B Genotype (SYREN Trial)}

\author{
Stéphane Chevaliez, ${ }^{1,2 *}$ Christophe Hézode, ${ }^{1,3 *}$ Alexandre Soulier, ${ }^{1,2}$ \\ Bruno Costes, ${ }^{2,4}$ Magali Bouvier-Alias, ${ }^{1,2}$ Stéphanie Rouanet, ${ }^{5}$ Juliette Foucher, ${ }^{6}$ \\ Jean-Pierre Bronowicki, ${ }^{7}$ Albert Tran, ${ }^{8}$ Isabelle Rosa, ${ }^{9}$ Philippe Mathurin, ${ }^{10}$ Laurent \\ Alric, ${ }^{11}$ Vincent Leroy, ${ }^{12}$ Patrice Couzigou, ${ }^{6}$ Ariane Mallat, ${ }^{1,3}$ Mariem Charaf-Eddine, ${ }^{5}$ \\ Gérard Babany, ${ }^{5}$ and Jean-Michel Pawlotsky ${ }^{1,2}$ \\ ${ }^{1}$ National Reference Center for Viral Hepatitis B, C and delta, Department of Virology, Hôpital Henri \\ Mondor, Université Paris-Est, Créteil, France; ${ }^{2}$ INSERM U955, Créteil, France; ${ }^{3}$ Department of \\ Hepatology and Gastroenterology, Hôpital Henri Mondor, Université Paris-Est, Créteil, France; \\ ${ }^{4}$ Department of Biochemistry, Hôpital Henri Mondor, Université Paris-Est, Créteil, France; ${ }^{5}$ Roche, \\ Neuilly-sur-Seine, France; ${ }^{6}$ Department of Hepatology and Gastroenterology, Hôpital Haut-Lévêque, \\ Université Victor Segalen Bordeaux 2, Pessac, France; ${ }^{7}$ Department of Hepatology and \\ Gastroenterology, INSERM U954, Centre Hospitalier Universitaire, Université Henri Poincaré, \\ Vandoeuvre-les-Nancy, France; ${ }^{8}$ Department of Hepatology and Gastroenterology, Hôpital de l'Archet, \\ Université de Nice, Nice, France; ${ }^{9}$ Department of Hepatology and Gastroenterology, Centre \\ Hospitalier Intercommunal, Créteil, France; ${ }^{10}$ Department of Hepatology and Gastroenterology, Hôpital \\ Claude Huriez, Université de Lille, Lille, France; ${ }^{11}$ Department of Internal Medicine, Hôpital Purpan, \\ Université de Toulouse, Toulouse, France; ${ }^{12}$ Department of Hepatology and Gastroenterology, Hôpital \\ de la Tronche, Université de Grenoble, Grenoble, France.
}

\section{SHORT TITLE: High-Dose peg-IFN and Ribavirin and IL28B in HCV nonresponders}

*These two authors equally contributed to the work

Corresponding author: Prof. Jean-Michel Pawlotsky, MD, PhD, Department of Virology, Hôpital Henri Mondor, 51 avenue du Maréchal de Lattre de Tassigny, 94010 Créteil, France

Tel: +33-1-4981-2827; Fax: +33-1-4981-4831

E-mail : jean-michel.pawlotsky@hmn.aphp.fr 
Grant support: This study is investigator-initiated. It has been funded by Roche France, which provided the study drugs.

Abbreviations: HCV: hepatitis C virus; IFN: interferon; SNP: single nucleotide polymorphism; SVR: sustained virological response; MGB: minor groove binder; BMI: body mass index; OR: odds ratio.

Disclosures: Stéphane Chevaliez: Roche-Advisor; Christophe Hézode: RocheAdvisor and paid lectures; Alexandre Soulier: no conflict to disclose; Bruno Costes: no conflict to disclose; Magali Bouvier-Alias: no conflict to disclose; Stéphanie Rouanet: Roche-Employee; Juliette Foucher: no conflict to disclose; Jean-Pierre Bronowicki: Roche-Advisor and paid lectures; Albert Tran: Roche-Advisor and paid lectures; Isabelle Rosa: no conflict to disclose; Philippe Mathurin: Roche-Advisor and paid lectures; Laurent Alric: Roche-Advisor and paid lectures; Vincent Leroy: RocheAdvisor and paid lectures; Patrice Couzigou: no conflict to disclose; Ariane Mallat: no conflict to disclose; Mariem Charaf-Eddine: Roche-Employee; Gérard Babany: Roche-Employee; Jean-Michel Pawlotsky: Roche-Advisor and paid lectures.

Author contributions: S.C., C.H. and J.-M.P. designed the study, analyzed the results, interpreted them, wrote the manuscript and take scientific responsibility for its content; A.S. and B.C. designed the IL28B genotype assay and did the analyses; M.B. performed the clinical virology tests; S.R. did the statistical analysis; J.F., J.P.B., A.T., I.R., P.M., L.A., V.L., P.C., and A.M. included the patients and followed them; M.C.-E. and G.B. coordinated the practical aspects of the study; all authors reviewed the draft manuscript and participated in its finalization. 


\section{ABSTRACT}

\section{Background \& Aims}

In patients with chronic hepatitis $\mathrm{C}$ who failed to respond to standard therapy, high-dose pegylated interferon (IFN)- $\alpha$ and/or ribavirin could induce a stronger antiviral response and prevent treatment failure and HCV resistance when combined with direct acting antivirals. The influence of genetic determinants in this context remains unknown.

\section{Methods}

Eighty-three patients infected with HCV genotype 1 who were non-responsive to standard therapy received pegylated IFN- $\alpha 2 a$ (360 $\mu \mathrm{g}$ once per week or $180 \mu \mathrm{g}$ twice per week) with ribavirin (1.0-1.2 or 1.2-1.6 g/day) for up to 72 weeks. Virological responses were assessed at different time points, and the influence of the IL28B genotype was studied.

\section{Results}

At weeks 12 and 24 respectively, 47 (56.6\%) and 50 (60.2\%) patients achieved a 2-Log $\log _{10}$ or more decrease of HCV RNA levels; 8 (9.6\%) and 21 (25.3\%) patients had undetectable HCV RNA after 12 and 24 weeks of treatment, respectively. Patients with a CT IL28B genotype responded significantly better and earlier than those with a TT genotype. In multivariate analysis, the IL-28B genotype was an independent predictor of the virological responses at weeks 4, 12 and 24.

\section{Conclusions}

High-dose pegylated IFN- $\alpha$, with standard or high doses of ribavirin, induces a potent antiviral response in a substantial number of patients who did not respond to standard therapy. The $I L 28 B$ genotype is an independent predictor of the antiviral 
response. High-dose pegylated IFN- $\alpha$ in combination with ribavirin and protease inhibitors appears as an attractive option for future study in this population.

\section{Key-words}

Hepatitis C virus; nonresponder; high-dose pegylated IFN- $\alpha$; IL28B genotype. 


\section{INTRODUCTION}

Hepatitis C virus (HCV) chronically infects approximately 120-130 million individuals worldwide. ${ }^{1}$ Chronic HCV infection is a major cause of life-threatening liver disease, and approximately $20 \%$ of $\mathrm{HCV}$-infected patients develop cirrhosis. ${ }^{2}$ Indeed, $\mathrm{HCV}$ infection is the main indication for liver transplantation, and is becoming the leading cause of hepatocellular carcinoma in industrialized areas. ${ }^{2}$ Mortality related to HCV infection has been estimated at approximately 300,000 deaths per year.

$\mathrm{HCV}$ infection is curable by therapy. Current treatment is based on a combination of pegylated interferon (IFN)- $\alpha$ and ribavirin. In patients infected with HCV genotype 1, by far the most frequent HCV genotype worldwide, only $40 \%$ to $50 \%$ of such treatment lead to a cure of infection. ${ }^{3-5}$ Failure of IFN- $\alpha$-based treatments to eradicate HCV infection has been recently shown, at least partly, to be genetically determined. Single nucleotide polymorphisms (SNPs) in the region upstream of the IL28B (IFN- $\lambda 3$ ) gene in chromosome 19 have been identified to be strongly associated with the ability of pegylated IFN- $\alpha$ and ribavirin to cure HCV infection. ${ }^{6-8}$ The underlying mechanisms remain obscure.

In 2011, new treatments will be available for chronic HCV genotype 1 infection. They will be based on a combination of pegylated IFN- $\alpha$, ribavirin and a specific HCV protease inhibitor, telaprevir or boceprevir. Phase II and III clinical trials have shown that approximately $25 \%-35 \%$ of treatment-naïve patients, and $50 \%-60 \%$ of those who have previously failed on pegylated IFN- $\alpha$ and ribavirin alone, fail to 
eradicate HCV on such triple combination. ${ }^{9}{ }^{10} 11-17$ Treatment failure is principally due to an insufficient antiviral response to pegylated IFN- $\alpha$ and ribavirin, favoring the growth of protease inhibitor resistant viruses selected by the direct acting antiviral agent. $^{10,12,13,18}$ Therefore, a sufficient antiviral response to pegylated IFN- $\alpha$ and ribavirin is an absolute prerequisite in order to achieve cure of infection with new triple combination therapies without selecting for resistant viruses.

As recent reports indicated that the outcome of triple combinations with pegylated IFN- $\alpha$, ribavirin and an HCV protease inhibitor strongly depends on the ability of IFN- $\alpha$ and ribavirin to substantially reduce HCV replication, ${ }^{10,12,13,18}$ which has recently been shown to be strongly associated with IL28B polymorphisms, ${ }^{6-8,19}$, ${ }^{20}$ we decided to assess the ability of high doses of pegylated IFN- $\alpha$ with standard or high doses of ribavirin to induce a significant antiviral response in genotype 1 patients who failed to respond to a first course of therapy at standard doses and whether responsiveness to high-dose pegylated IFN- $\alpha$ and ribavirin is genetically driven in this population.

\section{PATIENTS AND METHODS}

\section{Patients}

The SYREN trial (ClinicalTrials.gov number NCT00412334) is a Phase II randomized, open-labeled clinical trial that included 104 patients infected with HCV genotype 1. These patients were previously treated with the standard combination of pegylated IFN- $\alpha 2 a$ (180 $\mu \mathrm{g}$ per week) and ribavirin (1.0-1.2 g/day according to body weight), received at least $80 \%$ of the treatment dose during the first 12 weeks of therapy, and did not achieve a 2-Log 10 or more decrease of HCV RNA levels 
between baseline and week 12 of treatment (the same HCV RNA assay was used at both time points).

The inclusion criteria were: male or female patient $\geq 18$ years; evidence of chronic HCV infection (positive anti-HCV antibody and detectable HCV RNA); HCV genotype 1; normal or elevated serum ALT level; compensated liver disease; liver fibrosis assessment by means of a noninvasive serological or elastographic test within 12 months prior to inclusion; negative pregnancy test for women of childbearing age at inclusion; efficacious double contraception (patient and partner) on treatment and 6 months thereafter; health insurance coverage; written informed consent. At least 4 weeks without treatment were required before inclusion.

Exclusion criteria included: current pregnancy or breastfeeding; male partner of a pregnant women; decompensated liver disease; hepatocellular carcinoma; human immunodeficiency virus, hepatitis A virus or hepatitis B virus coinfection; any other cause of liver disease; previous history of autoimmune disease, chronic lung disease, severe heart disease, organ transplantation, cancer; hemoglobin level $<12 \mathrm{~g} / \mathrm{dL}$ (women) or $<13 \mathrm{~g} / \mathrm{dL}$ (men); patient at increased risk of anemia or for whom anemia could be a vital risk; neutropenia $<1500$ cells $/ \mathrm{mm}^{3}$; thrombocytopenia $<75,000 / \mathrm{mm}^{3}$; creatininemia $>1.5$ times the upper limit of normal values; patient who withdrew from prior pegylated IFN- $\alpha 2 a$ and ribavirin treatment for hematological adverse events; previous history of allergy to experimental drugs or to one of their components; any antiviral, antineoplastic or immunomodulatory treatment within 6 months prior to inclusion, except pegylated IFN- $\alpha 2 a$ and ribavirin; active drug abuse or current chronic alcoholism; previous history of severe psychiatric disease; current treatment with anticonvulsants; thyroid disorder not controlled by medication; severe 
retinopathy or eye disorder related to diabetes or hypertension; poorly controlled high blood pressure; previous history or risk of vein thrombosis.

The goal of the SYREN trial was to evaluate the efficacy and safety of four intensified regimens of pegylated IFN- $\alpha 2 a$ and ribavirin in this population. The patients were randomized to receive pegylated IFN- $\alpha 2 a$, either $360 \mu \mathrm{g}$ once per week or $180 \mu \mathrm{g}$ twice per week, in combination with ribavirin, either 1.0-1.2 g/day or 1.2-1.6 g/day according to body weight, for the full duration of therapy. As per the protocol stopping rules, treatment was halted at weeks 12 or 24 in patients with a less than 0.5 - or 2.0-Log 10 drop of HCV RNA levels, respectively, or if HCV RNA was still detectable at week 48 . The planned treatment duration in the remaining patients was initially 48 weeks. An amendment was passed to prolong therapy for a total of 72 weeks at the same doses of pegylated IFN- $\alpha$ and ribavirin in patients who had undetectable HCV RNA at week 48 of therapy. The study was approved by an Institutional Review Board (Comité de Protection des Personnes, Hôpital Henri Mondor, Créteil, France).

All of the analyses have been performed on the intent-to-treat population, which included 98 non-responder patients who received at least one dose of study drug and had at least one HCV RNA measurement under treatment. After the report of a relationship between IL28B genotype and the response to IFN- $\alpha$-based therapy, another amendment was passed in order to allow us to test the patients for IL28B genotype. Eighty-three of the 98 patients gave their informed consent to the genetic testing and constitute the study population of this article. The baseline characteristics of the patients who did not give their informed consent did not differ from those in the study patients. As no significant differences in virological response rates were 
observed between the treatment groups at different time points, the patients from the 4 groups were considered together in this study.

\section{HCV RNA level monitoring}

HCV RNA levels were measured at baseline and at weeks 1, 2, 4, 12, 24, 48 and 72 of therapy. In the patients receiving 72 weeks of therapy, HCV RNA levels were also measured at week 96, i.e. 24 weeks after the end of treatment. The COBAS AmpliPrep ${ }^{\circledR} /$ COBAS TaqMan ${ }^{\circledR}$ automated real-time PCR platform (Roche Molecular Systems, Pleasanton, California). This assay has a lower limit of detection of $15 \mathrm{IU} / \mathrm{mL}$ and a lower limit of quantification of $43 \mathrm{IU} / \mathrm{mL} .{ }^{21}$ The sustained virological response (SVR) was defined as an undetectable HCV RNA 24 weeks after the end of therapy; the SVR corresponds to a cure of infection in more than $99 \%$ of cases. ${ }^{22}$

\section{IL28B polymorphism (rs12979860) determination}

IL28B genotype at SNP position rs12979860 was determined by means of an original real-time PCR method using genomic DNA extracted from frozen serum samples in conjunction with minor groove binder (MGB) probes. Briefly, free circulating nucleic acids were extracted from $400 \mu \mathrm{l}$ of serum by means of the QIAsymphony DNA Midi kit (Qiagen GmbH, Hilden, Germany) on the QIAsymphony SP automated extractor. rs12979860 genotyping was performed by means of realtime PCR in the $\operatorname{TaqMan}^{\circledR}$ Gene Expression Master Mix on the ABI 7300 Real-Time PCR system (Applied Biosystems, Foster City, California), with the following primers and probes: reverse primer: 5'-GAGCGCGGAGTGCAATTC-3'; forward primer: 5'TGCCTGTGCTGTACTGAA-3'; VIC-probe: 5'-TCCCCGAAGGCGTGA-3'; FAM- 
probe: 5'-AAGGCGCGAACCA-3'. Automated allele calling was performed by means of Sequence Detection System software version 1.4 (Applied Biosystems).

\section{Statistical analysis}

Statistical analysis was performed with SAS 9.1 software (SAS Institute Inc., Cary, North Carolina). Tests were two-sided and a type I error was set at 0.05 . Missing data were not replaced. The week 1 virological response was calculated between treatment start and day 7 of therapy. The second-phase slope was computed by linear regression using HCV RNA levels at days 8 and 28 of therapy. Comparisons between IL28B genotypes (CT versus TT) were performed using Chisquare test or Fisher's exact test for qualitative variables, and Student's $t$ test or Wilcoxon test for continuous variables.

The relationship between the virological responses at different time points and explanatory variables was analyzed by logistic regression. The variables were selected by univariate logistic regression among age, gender, IL28B polymorphisms, body mass index (BMI), duration of $\mathrm{HCV}$ infection, source of $\mathrm{HCV}$ infection, cirrhosis, subtype of HCV genotype, HCV RNA level changes during the first course of treatment, duration of the first course of treatment, baseline HCV RNA level, ALT level and $\gamma$-glutamyl transferase activity, number of pegylated IFN- $\alpha$ injections per week, and daily ribavirin dose. Significant variables after univariate regression analysis were entered into a stepwise multivariate model. Results are expressed as odds ratios (OR) with $95 \%$ confidence intervals.

The positive and negative predictive values, sensitivities and specificities of the IL28B genotypes for the virological responses at different time points were calculated. 


\section{Role of the funding source}

This study is investigator-initiated. It has been sponsored by Roche (Neuillysur-Seine, France). Roche also provided medication and support for statistical analysis.

\section{RESULTS}

\section{Characteristics of the study patients}

Table 1 shows the characteristics of the 83 patients who gave their consent for the IL28B analysis. All of them had undergone a first course of therapy with standard doses of pegylated IFN- $\alpha 2 a$ and ribavin, had received more than $80 \%$ of the pegylated IFN- $\alpha 2 a$ and ribavin dose, and had stopped therapy at week 12 because they failed to achieve a more than $2 \log _{10} \mathrm{HCV}$ RNA level drop. They were retreated with high-dose pegylated IFN- $\alpha$ combined with standard- or high-dose ribavirin. No significant differences (and no trend toward differences) in virological responses were observed between the 4 treatment groups (either $360 \mu \mathrm{g}$ once per week or $180 \mu \mathrm{g}$ twice per week of pegylated IFN- $\alpha$, combined with a standard or a high dose of ribavirin) at different time points. In particular, there was no influence of a standard or a high dose of ribavirin on virological outcomes (data not shown). Thus, the patients from the 4 groups were pooled together for analysis in order to assess the virological response to retreatment with a high dose of pegylated IFN- $\alpha$ (with a standard or high dose of ribavirin) and the influence of the IL28B genotype on this response. Figure 1 
shows a flow chart of patient disposition in the trial. The following results are based on intent-to-treat analysis.

Only 3 patients had a CC genotype at IL28B SNP position rs12979860. Their characteristics at baseline did not differ from those in the remaining patients. Two of them did not achieve a 2- $\log _{10}$ HCV RNA decline and stopped therapy at week 24 as per the protocol stopping rule; the third one responded but failed to achieve an SVR. The CC patients were thus removed from the analysis to allow for comparison of the $55(66.3 \%)$ CT and the $25(30.1 \%)$ TT patients. The characteristics of the patients did not differ between these two groups. In particular, there was no significant difference in the mean HCV RNA levels at baseline $(p=0.76)($ Table 1$)$.

\section{Virological response to high-dose pegylated IFN- $\alpha$ with ribavirin}

At week 12, 48 of the 83 patients $(57.8 \%)$ who had not responded to a standard treatment dose (less than 2-Log 10 HCV RNA level drop) achieved a 2-Log ${ }_{10}$ or more HCV RNA level drop and 8 (9.6\%) had undetectable HCV RNA (<15 IU/mL). At week 24, 51 patients (61.4\%) achieved a 2-Log 10 or more HCV RNA level drop and $21(25.3 \%)$ had undetectable HCV RNA.

Due to a high incidence of post-treatment relapses, only 5 patients $(6.0 \%)$ achieved an SVR. HCV RNA was undetectable at week 12 of therapy in all of them, and already at week 4 in one of them. Only one of the 5 patients who achieved an SVR had received the full 72 weeks of therapy, the remaining 4 having discontinued earlier due to adverse events, patient or investigator decision.

Week 12 virological response to retreatment with high-dose pegylated IFN- $\alpha$ with ribavirin according to the IL28B genotype 
At week 12 of retreatment with high-dose pegylated IFN- $\alpha$ with standard- or high-dose ribavirin, the mean $\pm S D \log _{10} \mathrm{HCV}$ RNA level decrease was significantly greater than during the first course of therapy with a standard dose of pegylated IFN$\alpha$ and ribavirin in both patients with a CC and a TT IL28B genotype: $-2.78 \pm 1.59$ vs $-1.04 \pm 0.55(p<0.0001)$, and $-1.72 \pm 0.90$ vs $-0.86 \pm 0.65(p=0.0015)$, respectively.

\section{Kinetics of virological response to high-dose pegylated IFN- $\alpha$ with}

\section{ribavirin according to the IL28B genotype}

As shown in Figure 2 and in Table 2, patients with a CT genotype responded significantly better (and earlier) to high-dose pegylated IFN- $\alpha$ and ribavirin than those with a TT genotype. Indeed, the proportions of CT patients with a more than $0.5,1.0$, or 2.0 $\log _{10}$ HCV RNA decrease were significantly higher than those in TT patients at weeks 2, 4, and 12-24, respectively. At weeks 24, 48 and at week 72 (end of treatment in patients who had undetectable HCV RNA at week 48), the proportion of patients with an undetectable HCV RNA was significantly higher in the CT patients than in the TT patients. The 5 patients who achieved an SVR were all in the CT group (9.1\% vs 0\%, not significant).

As shown in Figure 2, the average HCV RNA decline during the first 7 days of therapy, that combines both first- and second-phase HCV RNA declines, was slightly but not significantly greater in CT than in TT patients $\left(-0.35 \pm 0.49\right.$ vs $-0.24 \pm 0.34 \log _{10}$ $\mathrm{IU} / \mathrm{mL}$, respectively; $p=0.33$ ). In contrast, the average weekly HCV RNA decline between days 8 and 28 of therapy, which accurately measures the second-phase decline, was significantly greater in CT than in TT patients $(-0.28 \pm 0.17$ vs $-0.18 \pm 0.12$ $\log _{10} \mathrm{IU} / \mathrm{mL} /$ week, respectively; $\left.p=0.004\right)$. 
Predictors of virological responses to high-dose pegylated IFN- $\alpha$ and ribavirin

As shown in Table 3, the IL-28B genotype was an independent predictor of the virological response at all tested time points, with CT patients being significantly more likely to respond than TT patients. Other predictors of response included female gender, body mass index (paradoxically, bigger patients responded better to high-dose therapy), the absence of cirrhosis, a more than $0.5 \log _{10}$ HCV RNA decrease during the first course of therapy with standard doses of pegylated IFN- $\alpha$ and ribavirin, and a low HCV RNA level at baseline (Table 3).

Predictive value of the IL28B genotype on virological responses to highdose pegylated IFN- $\alpha$ and ribavirin

Table 4 shows the positive and negative predictive values, sensitivities and specificities of the IL28B genotype for the virological responses to high-dose pegylated IFN- $\alpha$ and ribavirin at weeks 4,12 and 24 .

\section{Adverse events}

Every patient experienced at least one adverse event during the study period; 23 of them $(27.7 \%)$ experienced at least one severe adverse event. Treatment discontinuation due to an adverse event or to a severe adverse event has been observed in $11(13.3 \%)$ and $6(7.2 \%)$ cases, respectively. Table 5 shows the most frequent $(\geq 10 \%)$ adverse events observed in the 83 patients during the trial. In contrast with a recent observation in patients receiving a standard dose of pegylated IFN- $\alpha$ and ribavirin, ${ }^{23}$ no significant difference was observed between CT and TT patients (data not shown). 


\section{DISCUSSION}

In this study, patients chronically infected with HCV genotype 1 who failed to respond to a standard dose of pegylated IFN- $\alpha$ and ribavirin by a more than $2-\log _{10}$ HCV RNA level drop were retreated with a high dose of pegylated IFN- $\alpha 2 a$ and a standard or high dose of ribavirin. High-dose pegylated IFN- $\alpha 2 a$ was administered for the full duration of therapy, which was extended to 72 weeks if HCV RNA was undetectable at week 48. In this respect, the design of the trial was original, as formerly published retreatment trials used either standard doses of pegylated IFN- $\alpha$ and ribavirin for the full treatment course or short-term induction with high-dose pegylated IFN- $\alpha$ at the beginning of therapy. ${ }^{24-27}$ These studies generally also included patients who responded by a more than 2- $\log _{10}$ HCV RNA level drop at week 12 but subsequently failed to achieve an SVR during the first course of therapy. In spite of these differences, only 5 patients in this trial (6\%) achieved an SVR, all of them belonging to the CT group.

An important finding in this study was that, in patients who were not able to achieve a $2.0 \log _{10}$ drop of HCV RNA levels at week 12 of treatment with standard doses of pegylated IFN- $\alpha$ and ribavirin, the use of a high dose of pegylated IFN- $\alpha 2 a$ induced a substantial antiviral response at weeks 12 and $24\left(\geq 2.0 \log _{10} \mathrm{HCV}\right.$ RNA level reduction) in more than half of cases, with approximately a quarter of the patients achieving undetectable HCV RNA at week 24. Although our study was not powered to assess this hypothesis, the lack of any trend toward a difference between the 4 treatment arms, and between the patients who received a standard and a high dose of ribavirin, suggests that the high dose of pegylated IFN- $\alpha 2 a$ used was 
responsible for the significantly greater antiviral efficacy observed, regardless of pegylated IFN- $\alpha$ frequency of administration (once or twice a week) and of the ribavirin dose administered. However, a marginal role for the latter could not be ruled out by our analysis and would require further analyses in larger groups of patients.

The present study also demonstrates that the ability of high-dose pegylated IFN- $\alpha$ with a standard or high dose of ribavirin to induce a significant antiviral response in prior non-responders to standard doses is under the influence of genetic determinants. Indeed, both patients with a CT and a TT genotype at SNP position rs12979860 responded significantly better to retreatment with high-dose pegylated IFN- $\alpha$ than to the first course of therapy with standard-dose pegylated IFN- $\alpha$. Nevertheless, patients with a CT genotype responded significantly better, and earlier, to high-dose retreatment than patients with a TT genotype (Figure 2). These findings are in keeping with recent reports showing that, in treatment-naïve patients infected with HCV genotype 1, CT patients respond better than TT patients to standard doses of pegylated IFN- $\alpha$ and ribavirin. ${ }^{6-8,19,20}$ Interestingly, CT patients had less favorable baseline parameters, such as a higher BMI and a higher proportion of males (not significant), than TT patients, further emphasizing the importance of the genetic background of the host in the response to IFN- $\alpha$.

A recent study assessing frequent viral kinetics in treatment-naïve patients receiving standard doses of pegylated IFN- $\alpha$ and ribavirin has shown nearly identical early viral kinetics among CT and TT patients. ${ }^{28}$ CC patients, who achieve the highest rates of viral clearance, had a significantly steeper first-phase HCV RNA level decline than both CT and TT patients, while their second-phase slopes were not different. $^{28}$ This suggested that the $I L 28 B$ genotype essentially influences the ability of the patients to mount a potent direct antiviral response against HCV in response to 
IFN- $\alpha$. Our data suggest that, when higher doses of pegylated IFN- $\alpha$ are used, CT patients respond significantly better than TT patients. In addition, the maximum effect of the IL28B genotype in our study was on the second-phase decline, which measures the progressive clearance of infected cells. High doses of pegylated IFN- $\alpha$ could trigger antiviral mechanisms that are not involved when standard doses are used, and/or the lower level of "resistance" of cells from CT patients to the action of IFN could allow them to respond when exposure is increased.

Our sampling schedule did not allow us to study the first-phase decline in our patients. We cannot rule out a role for a difference between CT and TT patients in the first-phase decline that would ultimately influence the second-phase decline. Indeed, in patients who are naturally poorly responsive to IFN- $\alpha$ and ribavirin, a modest reduction of $\mathrm{HCV}$ RNA levels below a threshold that triggers infected cell clearance (or cure ?) could have visible consequences on the second-phase decline only. These hypotheses will be difficult to verify unless appropriate experimental models are available and the molecular mechanisms underlying the relationship between IL28B polymorphisms and $\mathrm{HCV}$ response to IFN- $\alpha$-based therapy are unraveled.

Overall, our data suggest that high-dose pegylated IFN- $\alpha$, in combination with a standard or a high dose of ribavirin, is an interesting option for combination with telaprevir or boceprevir in order to minimize the risk of resistance selection and increase the SVR rates in non-responders to prior standard therapy. This is reinforced by the fact that these treatments would be given for 24 to 48 weeks, and the antiviral effect was sustained over this duration in our study in patients who responded. The minimal antiviral effect of pegylated IFN- $\alpha$ and ribavirin to achieve a high cure rate is still unknown. Phase II and III trials with pegylated IFN- $\alpha 2 b$, ribavirin 
and boceprevir, which included a lead-in phase with pegylated IFN- $\alpha 2 b$ and ribavirin alone, suggested that it could be of the order of $1.0-1.5 \log _{10} \mathrm{IU} / \mathrm{mL}$ at week $4 .^{10,15,16}$ Results from the REALIZE trial with pegylated IFN- $\alpha 2 a$, ribavirin and telaprevir, which included a lead-in phase with pegylated IFN- $\alpha 2 a$ and ribavirin alone, are awaited.

Although the IL28B genotype is a strong, independent predictor of the ability of high-dose pegylated IFN- $\alpha$ and ribavirin to induce an antiviral response in nonresponders, the individual predictive value of this marker was not very high in our study. Specifically, a substantial number of TT patients were able to achieve a significant antiviral response on treatment. Therefore IL28B genotyping should not be recommended as a tool to deny high-dose pegylated IFN- $\alpha$ and ribavirin therapy in non-responders retreated with a triple combination. Nevertheless, non-responder CT patients represent an ideal population for this strategy. Stratification on the IL28B genotype should therefore be recommended in future trials assessing strategies based on high-dose pegylated IFN- $\alpha$ and ribavirin.

Other predictors of response at different time points included a female gender, the absence of cirrhosis, a more than $0.5 \log _{10} \mathrm{HCV}$ RNA decline during the first course of therapy at standard doses and a low baseline HCV RNA level, parameters known to be associated with better SVR rates in HCV-infected patients. ${ }^{3-5}$. The noted effects of increased BMI appeared paradoxical, as bigger patients had a better response at weeks 12 and 24 . This could be explained by the fact that higher doses work particularly well in patients in whom the principal cause of failure was a high BMI, responsible for insufficient IFN- $\alpha$ exposure during the first treatment course.

In conclusion, this study shows that high-dose pegylated IFN- $\alpha$, with standard or high doses of ribavirin, is able to induce a potent antiviral response in a substantial number of patients who did not respond or responded poorly to a standard dose 
regimen. Patients with a CT IL28B genotype respond significantly better, and earlier, to high-dose pegylated IFN- $\alpha$ and ribavirin than those with a TT genotype. High-dose pegylated IFN- $\alpha$ and ribavirin therefore appears as a viable option to optimize HCV clearance rates in patients who failed on standard therapy and are retreated with a triple combination of pegylated IFN- $\alpha$, ribavirin and a protease inhibitor. This option, along with the ideal treatment schedule (our results suggest that high-dose pegylated IFN- $\alpha 2 a$ should be administered once weekly, but the question remains open for pegylated IFN- $\alpha 2 b$ which bears different pharmacokinetic properties), should now be studied in prospective clinical trials according to the IL28B genotype.

\section{ACKNOWLEDGMENTS}

We thank the patients and nurses for their involvement in the study. 


\section{FIGURE LEGENDS}

Figure 1. Flow chart of patient disposition. "Other" causes of treatment interruption include: patient's decision $(n=4)$, investigator's decision $(n=3)$, death unrelated to the study drugs $(n=1)$.

Figure 2. Mean $\pm S D$ HCV RNA level reductions from baseline in patients with a CT genotype (black circles) or a TT genotype (black squares). As a comparator, mean \pm SD HCV RNA level reductions at week 12 of a prior course of therapy with standard doses of pegylated IFN- $\alpha$ and ribavirin in the same patients are shown as dotted lines. P values are for CT vs TT patients. NS: not significant. 


\section{REFERENCES}

1. Global Burden of Hepatitis C Working Group. Global burden of disease (GBD) for hepatitis C. J Clin Pharmacol 2004;44:20-9.

2. Perz JF, Armstrong GL, Farrington LA, Hutin YJ, Bell BP. The contributions of hepatitis $B$ virus and hepatitis $C$ virus infections to cirrhosis and primary liver cancer worldwide. J Hepatol 2006;45:529-38.

3. Fried MW, Shiffman ML, Reddy KR, Smith C, Marinos G, Goncales FL, Jr., Haussinger D, Diago M, Carosi G, Dhumeaux D, Craxi A, Lin A, Hoffman J, Yu J. Peginterferon alfa-2a plus ribavirin for chronic hepatitis $C$ virus infection. N Engl J Med 2002;347:975-82.

4. Hadziyannis SJ, Sette H, Jr., Morgan TR, Balan V, Diago M, Marcellin P, Ramadori G, Bodenheimer H, Jr., Bernstein D, Rizzetto M, Zeuzem S, Pockros PJ, Lin A, Ackrill AM. Peginterferon-alpha2a and ribavirin combination therapy in chronic hepatitis C: a randomized study of treatment duration and ribavirin dose. Ann Intern Med 2004;140:346-55.

5. Manns MP, McHutchison JG, Gordon SC, Rustgi VK, Shiffman M, Reindollar R, Goodman ZD, Koury K, Ling M, Albrecht JK. Peginterferon alfa-2b plus ribavirin compared with interferon alfa-2b plus ribavirin for initial treatment of chronic hepatitis C: a randomised trial. Lancet 2001;358:958-65.

6. Ge D, Fellay J, Thompson AJ, Simon JS, Shianna KV, Urban TJ, Heinzen EL, Qiu P, Bertelsen AH, Muir AJ, Sulkowski M, McHutchison JG, Goldstein DB. Genetic variation in IL28B predicts hepatitis C treatment-induced viral clearance. Nature 2009;461:399-401. 
7. Suppiah V, Moldovan M, Ahlenstiel G, Berg T, Weltman M, Abate ML, Bassendine M, Spengler U, Dore GJ, Powell E, Riordan S, Sheridan D, Smedile A, Fragomeli V, Muller T, Bahlo M, Stewart GJ, Booth DR, George J. IL28B is associated with response to chronic hepatitis C interferon-alpha and ribavirin therapy. Nat Genet 2009;41:1100-4.

8. Tanaka $\mathrm{Y}$, Nishida N, Sugiyama M, Kurosaki M, Matsuura K, Sakamoto N, Nakagawa M, Korenaga M, Hino K, Hige S, Ito Y, Mita E, Tanaka E, Mochida S, Murawaki Y, Honda M, Sakai A, Hiasa Y, Nishiguchi S, Koike A, Sakaida I, Imamura $\mathrm{M}$, Ito $\mathrm{K}$, Yano $\mathrm{K}$, Masaki $\mathrm{N}$, Sugauchi $\mathrm{F}$, Izumi $\mathrm{N}$, Tokunaga $\mathrm{K}$, Mizokami M. Genome-wide association of IL28B with response to pegylated interferon-alpha and ribavirin therapy for chronic hepatitis C. Nat Genet 2009;41:1105-9.

9. Hezode C, Forestier N, Dusheiko G, Ferenci P, Pol S, Goeser T, Bronowicki JP, Bourliere M, Gharakhanian S, Bengtsson L, McNair L, George S, Kieffer T, Kwong A, Kauffman RS, Alam J, Pawlotsky JM, Zeuzem S. Telaprevir and peginterferon with or without ribavirin for chronic HCV infection. N Engl J Med 2009;360:1839-50.

10. Kwo PY, Lawitz EJ, McCone J, Schiff ER, Vierling JM, Pound D, Davis MN, Galati JS, Gordon SC, Ravendhran N, Rossaro L, Anderson FH, Jacobson IM, Rubin R, Koury K, Pedicone LD, Brass CA, Chaudhri E, Albrecht JK. Efficacy of boceprevir, an NS3 protease inhibitor, in combination with peginterferon alfa-2b and ribavirin in treatment-naive patients with genotype 1 hepatitis $\mathrm{C}$ infection (SPRINT-1): an open-label, randomised, multicentre phase 2 trial. Lancet 2010;376:705-16. 
11. McHutchison JG, Everson GT, Gordon SC, Jacobson IM, Sulkowski M, Kauffman R, McNair L, Alam J, Muir AJ. Telaprevir with peginterferon and ribavirin for chronic HCV genotype 1 infection. N Engl J Med 2009;360:182738.

12. McHutchison JG, Manns MP, Muir AJ, Terrault NA, Jacobson IM, Afdhal NH, Heathcote EJ, Zeuzem S, Reesink HW, Garg J, Bsharat M, George S, Kauffman RS, Adda N, Di Bisceglie AM. Telaprevir for previously treated chronic HCV infection. N Engl J Med 2010;362:1292-303.

13. Berg T, McHutchison JG, Adda N, Poordad F, Shiffman ML, Ferenci P, Heathcote J, Pawlotsky JM, Zeuzem S, Reesink HW, Dusheiko G, Martin E, Alexanderian D, George S, Muir AJ. SVR with telaprevir, peginterferon alfa-2a and ribavirin in $\mathrm{HCV}$ patients with well-characterized prior null-response, partial response, viral breakthrough or relapse after PR. J Hepatol 2010;52 (Suppl. 1):S2.

14. Jacobson IM, McHutchison JG, Dusheiko GM, Di Bisceglie AM, Reddy R, Bzowej NH, Marcellin P, Muir AJ, Bengtsson L, Dunn AM, Adda N, George S, Kauffman RS, Zeuzem S. Telaprevir in combination with peginterferon and ribavirin in genotype $1 \mathrm{HCV}$ treatment-naive patients: final results of Phase 3 ADVANCE study. Hepatology 2010;52 (suppl.):427A.

15. Bacon BR, Gordon SC, Lawitz E, Marcellin P, Vierling JM, Zeuzem S, Poordad F, Boparai N, Burroughs M, Brass CA, Albrecht JK, Esteban R. HCV RESPOND-2 final results: high sustained virologic response among genotype 1 previous nonresponders and relapsers to peginterferon/ribavirin when retreated with boceprevir plus PegIntron (peginterferon alfa-2b)/ribavirin. Hepatology 2010;52 (suppl.):430A. 
16. Poordad F, McCone J, Bacon BR, Bruno S, Manns MP, Sulkowski MS, Jacobson IM, Reddy KR, Boparai N, Sniukiene V, Brass CA, Albrecht JK, Bronowicki JP. Boceprevir (BOC) combined with peginterferon alfa-2b/ribavirin $(P / R)$ for treatment-naive patients with hepatitis $\mathrm{C}$ virus $(\mathrm{HCV})$ genotype 1: SPRINT-2 final results. Hepatology 2010;52 (suppl.):402A.

17. Sherman KE, Flamm SL, Afdhal NH, Nelson DR, Sulkowski MS, Everson GT, Fried MW, Kleber K, Martin M, Sankoh AJ, Kauffman RS, George S, Wright $\mathrm{Cl}$, Poordad F. Telaprevir in combination with peginterferon alfa2a and ribavirin for 24 or 48 weeks in treatment-naive genotype $1 \mathrm{HCV}$ patients who achieved an extended rapid viral response: final results of Phase 3 ILLUMINATE study. Hepatology 2010;52 (suppl.):401A.

18. Pawlotsky JM. Treatment failure and resistance with direct acting antiviral drugs against hepatitis C virus. Hepatology 2011 ;in press.

19. Rauch A, Kutalik Z, Descombes P, Cai T, Di lulio J, Mueller T, Bochud M, Battegay M, Bernasconi E, Borovicka J, Colombo S, Cerny A, Dufour JF, Furrer H, Gunthard HF, Heim M, Hirschel B, Malinverni R, Moradpour D, Mullhaupt B, Witteck A, Beckmann JS, Berg T, Bergmann S, Negro F, Telenti A, Bochud PY. Genetic variation in IL28B is associated with chronic hepatitis C and treatment failure: a genome-wide association study. Gastroenterology 2010;138:1338-45.

20. McCarthy JJ, Li JH, Thompson A, Suchindran S, Lao XQ, Patel K, Tillmann HL, Muir AJ, McHutchison JG. Replicated association between an IL28B gene variant and a sustained response to pegylated interferon and ribavirin. Gastroenterology 2010;138:2307-14. 
21. Chevaliez S, Bouvier-Alias M, Brillet R, Pawlotsky JM. Overestimation and underestimation of hepatitis C virus RNA levels in a widely used real-time polymerase chain reaction-based method. Hepatology 2007;46:22-31.

22. Swain MG, Lai MY, Shiffman ML, Cooksley WG, Zeuzem S, Dieterich DT, Abergel A, Pessoa MG, Lin A, Tietz A, Connell EV, Diago M. A sustained virologic response is durable in patients with chronic hepatitis $C$ treated with peginterferon alfa-2a and ribavirin. Gastroenterology 2010;139:1593-601.

23. Lotrich FE, Loftis JM, Ferrell RE, Rabinovitz M, Hauser P. IL28B polymorphism is associated with both side effects and clearance of hepatitis $\mathrm{C}$ during interferon-alpha therapy. J Interferon Cytokine Res 2010.

24. Jensen DM, Marcellin P, Freilich B, Andreone P, Di Bisceglie A, BrandaoMello CE, Reddy KR, Craxi A, Martin AO, Teuber G, Messinger D, Thommes JA, Tietz A. Re-treatment of patients with chronic hepatitis $C$ who do not respond to peginterferon-alpha2b: a randomized trial. Ann Intern Med 2009;150:528-40.

25. Poynard T, Colombo M, Bruix J, Schiff E, Terg R, Flamm S, Moreno-Otero R, Carrilho F, Schmidt W, Berg T, McGarrity T, Heathcote EJ, Goncales F, Diago M, Craxi A, Silva M, Bedossa P, Mukhopadhyay P, Griffel L, Burroughs M, Brass C, Albrecht J. Peginterferon alfa-2b and ribavirin: effective in patients with hepatitis $\mathrm{C}$ who failed interferon alfa/ribavirin therapy. Gastroenterology 2009;136:1618-28 e2.

26. Shiffman ML, Di Bisceglie AM, Lindsay KL, Morishima C, Wright EC, Everson GT, Lok AS, Morgan TR, Bonkovsky HL, Lee WM, Dienstag JL, Ghany MG, Goodman ZD, Everhart JE. Peginterferon alfa-2a and ribavirin in patients with 
chronic hepatitis $\mathrm{C}$ who have failed prior treatment. Gastroenterology 2004;126:1015-23.

27. Taliani G, Gemignani G, Ferrari C, Aceti A, Bartolozzi D, Blanc PL, Capanni M, Esperti F, Forte P, Guadagnino V, Mari T, Marino N, Milani S, Pasquazzi C, Rosina F, Tacconi D, Toti M, Zignego AL, Messerini L, Stroffolini T. Pegylated interferon alfa-2b plus ribavirin in the retreatment of interferon-ribavirin nonresponder patients. Gastroenterology 2006;130:1098-106.

28. Neumann A, Bibert S, Haagmans B, Soulier A, Negro F, Lagging M, Ferrari C, Zeuzem S, Pawlotsky JM, Schalm S, Bochud PY. IL28B polymorphism is significantly correlated with IFN antiviral effectiveness already on first day of pegylated interferon alpha and ribavirin therapy of chronic HCV infection. $\mathrm{J}$ Hepatol 2010;52 (Suppl. 1):S468. 
Table 1. Baseline characteristics of the patients, according to the IL-28B genotype (TT, CT and CC at SNP position rs12979860).

BMI: body mass index; ALT: alanine aminotransferase; PegIFN: pegylated IFN- $\alpha$.

\begin{tabular}{|c|c|c|c|c|}
\hline Characteristics & All patients & TT & CT & $\mathrm{CC}$ \\
\hline $\mathrm{N}$ & 83 & 25 & 55 & 3 \\
\hline Males [n (\%)] & $57(68.7 \%)$ & $13(52.0 \%)$ & $41(74.5 \%)$ & $3(100 \%)$ \\
\hline Age (years) [median (range)] & $50(34-68)$ & $49(34-66)$ & $50(37-68)$ & $52(47-59)$ \\
\hline \multicolumn{5}{|l|}{ First course of therapy } \\
\hline First treatment duration (weeks) [mean \pm SD] & $28.4 \pm 4.0$ & $28.7 \pm 13$ & $28.0 \pm 14.5$ & $33.6 \pm 7.8$ \\
\hline Baseline HCV RNA level $\left(\log _{10} I \mathrm{IU} / \mathrm{mL}\right)[\mathrm{mean} \pm \mathrm{SD}]$ & $6.1 \pm 0.8$ & $6.3 \pm 0.6$ & $6.1 \pm 0.8$ & $6.0 \pm 0.4$ \\
\hline HCV RNA level at week $12\left(\log _{10} \mathrm{IU} / \mathrm{mL}\right)[$ mean $\pm S D]$ & $5.2 \pm 0.9$ & $5.4 \pm 0.7$ & $5.1 \pm 1.0$ & $5.2 \pm 0.9$ \\
\hline BMI $\left(\mathrm{kg} / \mathrm{m}^{2}\right)^{\mathrm{a}}[$ median (range)] & $25.6(18.5-39.5)$ & $25.1(20.3-37.6)$ & $25.7(18.5-39.5)$ & $25.3(24.8-36.8)$ \\
\hline $\mathrm{BMI} \geq 25 \mathrm{~kg} / \mathrm{m}^{2}[\mathrm{n}(\%)]$ & $46 / 77(59.7 \%)$ & $11 / 22(50.0 \%)$ & $33 / 52(63.5 \%)$ & $2 / 3(66.7 \%)$ \\
\hline $\mathrm{BMI} \geq 30 \mathrm{~kg} / \mathrm{m}^{2}[\mathrm{n}(\%)]$ & $13 / 77(16.9 \%)$ & $2 / 22(9.1 \%)$ & $10 / 52(19.2 \%)$ & $1 / 3(33.3 \%)$ \\
\hline Cirrhosis $^{b}[\mathrm{n}(\%)]$ & $37(44.6 \%)$ & $11(44.0 \%)$ & $24(43.6 \%)$ & $2(66.7 \%)$ \\
\hline \multicolumn{5}{|l|}{ 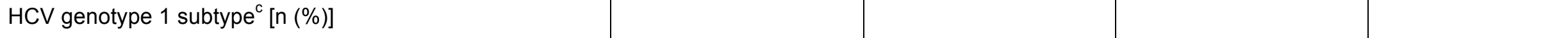 } \\
\hline $1 \mathrm{a}$ & $35(42.2 \%)$ & $12(48.0 \%)$ & $23(41.8 \%)$ & $0(0.0 \%)$ \\
\hline $1 \mathrm{~b}$ & $44(53.0 \%)$ & $12(48.0 \%)$ & $30(54.5 \%)$ & $2(66.7 \%)$ \\
\hline Other $^{d}$ & $4(4.8 \%)$ & $1(4.0 \%)$ & $2(3.6 \%)$ & $1(33.3 \%)$ \\
\hline Baseline ALT level (IU/mL) [median (range)] & $98(16-554)$ & $109(27-440)$ & $81(16-554)$ & $103(41-166)$ \\
\hline Baseline HCV RNA level $\left(\log _{10} I U / m L\right)$ [mean $\left.\pm S D\right]$ & $6.5 \pm 0.6$ & $6.5 \pm 0.6$ & $6.5 \pm 0.5$ & $6.4 \pm 0.1$ \\
\hline Baseline HCV RNA level >800,000 IU/mL [n (\%)] & $70(84.3 \%)$ & $21(84.0 \%)$ & $46(83.6 \%)$ & $3(100.0 \%)$ \\
\hline \multicolumn{5}{|l|}{ Treatment received } \\
\hline PegIFN 360 qw + ribavirin standard dose & $21(25.3 \%)$ & $5(20.0 \%)$ & $16(29.1 \%)$ & $0(0 \%)$ \\
\hline PegIFN 180 biw + ribavirin standard dose & $22(26.5 \%)$ & $8(32.0 \%)$ & $14(25.5 \%)$ & $0(0 \%)$ \\
\hline PegIFN 360 qw + ribavirin high dose & $18(21.7 \%)$ & $5(20.0 \%)$ & $12(21.8 \%)$ & $1(33.3 \%)$ \\
\hline PegIFN 180 biw + ribavirin high dose & $22(26.5 \%)$ & $7(28.0 \%)$ & $13(23.6 \%)$ & $2(66.7 \%)$ \\
\hline
\end{tabular}


${ }^{a}$ The body mass index (BMI) is the weight in kilograms divided by the square of the height in meters; BMI was available in 77 patients only, including 22 TT, 52 CT and 3 CC patients.

${ }^{\mathrm{b}}$ Cirrhosis was diagnosed by means of liver biopsy in 6 patients and noninvasive tests, including Fibrotest ${ }^{\circledR}$ and/or Fibroscan ${ }^{\circledR}$ in the remaining cases.

${ }^{\mathrm{c}} \mathrm{HCV}$ genotype and subtype were determined by means of direct sequence analysis of a portion of the HCV nonstructural $5 \mathrm{~B}$ gene followed by phylogenetic analysis.

${ }^{\mathrm{d}}$ Other HCV subtypes were subtype $1 \mathrm{i}$ in one patient with a CC genotype, $1 \mathrm{~h}$ and indeterminate in 2 patients with a CT genotype, and $1 \mathrm{i}$ in one patient with a

TT genotype. 
Table 2. Proportions of patients who achieved different magnitudes of HCV RNA level decline at different time points during and after treatment with high-dose pegylated IFN- $\alpha$ and ribavirin, according to the IL28B SNP rs12979860 genotype (TT vs CT); intentto-treat analysis. $p$ values are for comparison between $\mathrm{CT}$ and TT patients. $\mathrm{N}$ values vary with the availability of the information at each time point. NS: not significantly different. NA: not applicable as per the protocol (colored in gray).

\begin{tabular}{|c|c|c|c|c|c|c|c|c|c|c|c|}
\hline \multirow{2}{*}{$\begin{array}{l}\text { Treatment } \\
\text { week }\end{array}$} & \multirow{2}{*}{$\begin{array}{c}\text { rs12979860 } \\
\text { (IL-28B) genotype }\end{array}$} & \multirow{2}{*}{$\mathbf{N}$} & \multirow{2}{*}{$\begin{array}{l}\text { Failure* }^{*} \\
\text { n (\%) }\end{array}$} & \multicolumn{2}{|c|}{$\begin{array}{l}\text { HCV RNA level } \\
\text { reduction } \geq 0.5 \text { Log }_{10}\end{array}$} & \multicolumn{2}{|c|}{$\begin{array}{l}\text { HCV RNA level } \\
\text { reduction } \geq 1.0 \text { Log }_{10}\end{array}$} & \multicolumn{2}{|c|}{$\begin{array}{l}\text { HCV RNA level } \\
\text { reduction } \geq 2.0 \text { Log }_{10}\end{array}$} & \multicolumn{2}{|c|}{$\begin{array}{l}\text { Undetectable HCV } \\
\text { RNA (<15 IU/mL) }\end{array}$} \\
\hline & & & & n (\%) & $\mathbf{p}$ & n (\%) & p & n (\%) & p & n (\%) & p \\
\hline Week 1 & $\begin{array}{l}\text { TT } \\
\text { CT }\end{array}$ & $\begin{array}{l}24 \\
52\end{array}$ & NA & $\begin{array}{c}5(20.8) \\
16(30.8) \\
\end{array}$ & NS & $\begin{array}{c}0(0) \\
5(9.6)\end{array}$ & NS & $\begin{array}{c}0(0) \\
1(1.9)\end{array}$ & NS & $\begin{array}{l}0(0) \\
0(0)\end{array}$ & NS \\
\hline Week 2 & $\begin{array}{l}\text { TT } \\
\mathrm{CT} \\
\end{array}$ & $\begin{array}{l}25 \\
54 \\
\end{array}$ & NA & $\begin{array}{c}9(36.0) \\
35(64.8)\end{array}$ & 0.02 & $\begin{array}{c}4(16.0) \\
11(20.4)\end{array}$ & NS & $\begin{array}{c}0(0) \\
1(1.9)\end{array}$ & NS & $\begin{array}{l}0(0) \\
0(0)\end{array}$ & NS \\
\hline Week 12 & $\begin{array}{l}\mathrm{TT} \\
\mathrm{CT}\end{array}$ & $\begin{array}{l}25 \\
55\end{array}$ & $\begin{array}{c}1(4.0) \\
0(0)\end{array}$ & $\begin{array}{l}23(92.0) \\
50(90.9)\end{array}$ & NS & $\begin{array}{l}17(68.0) \\
45(81.8)\end{array}$ & NS & $\begin{array}{l}10(40.0) \\
37(67.3)\end{array}$ & 0.02 & $\begin{array}{c}0(0) \\
8(14.5)\end{array}$ & 0.05 \\
\hline Week 24 & $\begin{array}{l}\text { TT } \\
\text { CT }\end{array}$ & $\begin{array}{l}25 \\
55\end{array}$ & $\begin{array}{l}4(16.0) \\
7(12.7)\end{array}$ & $\begin{array}{l}20(80.0) \\
48(87.3)\end{array}$ & NS & $\begin{array}{l}16(64.0) \\
41(74.5)\end{array}$ & NS & $\begin{array}{l}11(44.0) \\
39(70.9)\end{array}$ & 0.02 & $\begin{array}{c}3(12.0) \\
18(32.7)\end{array}$ & 0.05 \\
\hline Week 48 & $\begin{array}{l}\mathrm{TT} \\
\mathrm{CT}\end{array}$ & $\begin{array}{l}25 \\
55\end{array}$ & NA & NA & NA & NA & NA & NA & NA & $\begin{array}{c}5(20.0) \\
24(43.6)\end{array}$ & 0.04 \\
\hline
\end{tabular}

According to the protocol stopping rules, i.e. $<0.5 \log _{10} \mathrm{HCV}$ RNA decline at week 12 or $<2.0 \log _{10}$ decline at week 24. 
Table 3. Predictors of HCV RNA level reduction relative to baseline at different time points in multivariate analysis. Parameters found to be associated with the HCV RNA level decrease at the specific time point with a $p$ value $\geq 0.10$ in univariate analysis were included in the multivariate analysis. OR: odds ratio; $95 \% \mathrm{Cl}$ : $95 \%$ confidence interval. Undetectable $\mathrm{means}<15 \mathrm{IU} / \mathrm{mL}$.

\begin{tabular}{|c|c|c|c|c|}
\hline Time point & $\begin{array}{l}\text { HCV RNA level } \\
\text { reduction }\end{array}$ & Predictors & OR $[95 \% \mathrm{Cl}]$ & $\mathbf{p}$ \\
\hline \multirow{3}{*}{ Week 4} & \multirow{3}{*}{$\geq 1.0 \log _{10}$} & Gender (female vs male) & $7.30[1.85 ; 28.57]$ & 0.005 \\
\hline & & IL-28B genotype (CT vs TT) & $6.46[1.77 ; 23.54]$ & 0.005 \\
\hline & & $\begin{array}{l}\text { Week } 12 \text { HCV RNA decrease during the first } \\
\text { course of therapy }\left(\geq 0.5 \log _{10} \text { vs }<0.5 \log _{10}\right)\end{array}$ & $5.76[1.34 ; 24.78]$ & 0.019 \\
\hline Week 12 & $\geq 2.0 \log _{10}$ & IL-28B genotype (CT vs TT) & $3.30[1.11 ; 9.83]$ & 0.032 \\
\hline \multirow{3}{*}{ Week 24} & \multirow{3}{*}{$\geq 2.0 \log _{10}$} & BMI $\left(\geq 26 \mathrm{~kg} / \mathrm{m}^{2} v s<26 \mathrm{~kg} / \mathrm{m}^{2}\right)^{\mathrm{b}}$ & $2.82[1.00 ; 7.95]$ & 0.050 \\
\hline & & IL-28B genotype (CT vs TT) & $3.72[1.26 ; 10.99]$ & 0.017 \\
\hline & & Baseline HCV RNA level $\left(<6 \log _{10}\right.$ vs $\left.\geq 6 \log _{10}\right)$ & $4.64[0.90 ; 23.84]$ & 0.066 \\
\hline
\end{tabular}


Table 4. Positive and negative predictive values, sensitivities and specificities of the IL28B genotype on the virological responses to high-dose pegylated IFN- $\alpha$ and ribavirin at weeks 4,12 and 24.

\begin{tabular}{|c|c|c|c|c|c|c|}
\hline $\begin{array}{c}\text { IL28B } \\
\text { polymorphism }\end{array}$ & Time point & $\begin{array}{l}\text { HCV RNA level } \\
\text { reduction }\end{array}$ & PPV (\%) & NPV (\%) & Sensitivity (\%) & Specificity (\%) \\
\hline TT & $\begin{array}{l}\text { Week } 4 \\
\text { Week } 12 \\
\text { Week } 24 \\
\text { Week } 24\end{array}$ & $\begin{array}{c}\geq 1.0 \log _{10} \\
\geq 2.0 \log _{10} \\
\geq 2.0 \log _{10} \\
\text { Undetectable }\end{array}$ & $\begin{array}{l}28.0 \\
40.0 \\
44.0 \\
12.0\end{array}$ & $\begin{array}{l}40.0 \\
32.7 \\
29.1 \\
67.3\end{array}$ & $\begin{array}{l}17.5 \\
21.3 \\
22.0 \\
14.3\end{array}$ & $\begin{array}{l}55.0 \\
54.5 \\
53.3 \\
62.7\end{array}$ \\
\hline CT & $\begin{array}{l}\text { Week } 4 \\
\text { Week } 12 \\
\text { Week } 24 \\
\text { Week } 24\end{array}$ & $\begin{array}{l}\geq 1.0 \log _{10} \\
\geq 2.0 \log _{10} \\
\geq 2.0 \log _{10} \\
\text { Undetectable }\end{array}$ & $\begin{array}{l}60.0 \\
67.3 \\
70.9 \\
32.7\end{array}$ & $\begin{array}{l}72.0 \\
60.0 \\
56.0 \\
88.0\end{array}$ & $\begin{array}{l}82.5 \\
78.7 \\
78.0 \\
85.7\end{array}$ & $\begin{array}{l}45.0 \\
45.5 \\
46.7 \\
37.3\end{array}$ \\
\hline
\end{tabular}


Table 5. Principal adverse events $(\geq 10 \%)$ in the 83 patients included in the study.

\begin{tabular}{|l|c|c|}
\hline Adverse event & $\begin{array}{c}\text { Number of } \\
\text { patients with the } \\
\text { adverse event }\end{array}$ & $\begin{array}{c}\% \text { of } \\
\text { patients with the } \\
\text { adverse event }\end{array}$ \\
\hline Asthenia & 62 & $74.7 \%$ \\
\hline Anemia & 44 & $53.0 \%$ \\
\hline Influenza-like illness & 37 & $44.6 \%$ \\
\hline Neutropenia & 31 & $37.3 \%$ \\
\hline Thrombocytopenia & 27 & $32.5 \%$ \\
\hline Pruritus & 25 & $30.1 \%$ \\
\hline Insomnia & 22 & $26.5 \%$ \\
\hline Anger & 22 & $26.5 \%$ \\
\hline Headache & 20 & $24.1 \%$ \\
\hline Nausea & 20 & $24.1 \%$ \\
\hline Cough & 19 & $22.9 \%$ \\
\hline Dry skin & 19 & $22.9 \%$ \\
\hline Dyspnea & 18 & $21.7 \%$ \\
\hline Diarrhea & 16 & $19.3 \%$ \\
\hline Sleep disorder & 15 & $18.1 \%$ \\
\hline Leukopenia & 14 & $16.9 \%$ \\
\hline Anorexia & 11 & $13.3 \%$ \\
\hline Decreased appetite & 11 & $13.3 \%$ \\
\hline Eczema & 10 & $12.0 \%$ \\
\hline Myalgia & 10 & $12.0 \%$ \\
\hline Back pain & 9 & $12.0 \%$ \\
\hline Depression & 9 & $10.8 \%$ \\
\hline Alopecia & $10 \%$ \\
\hline
\end{tabular}




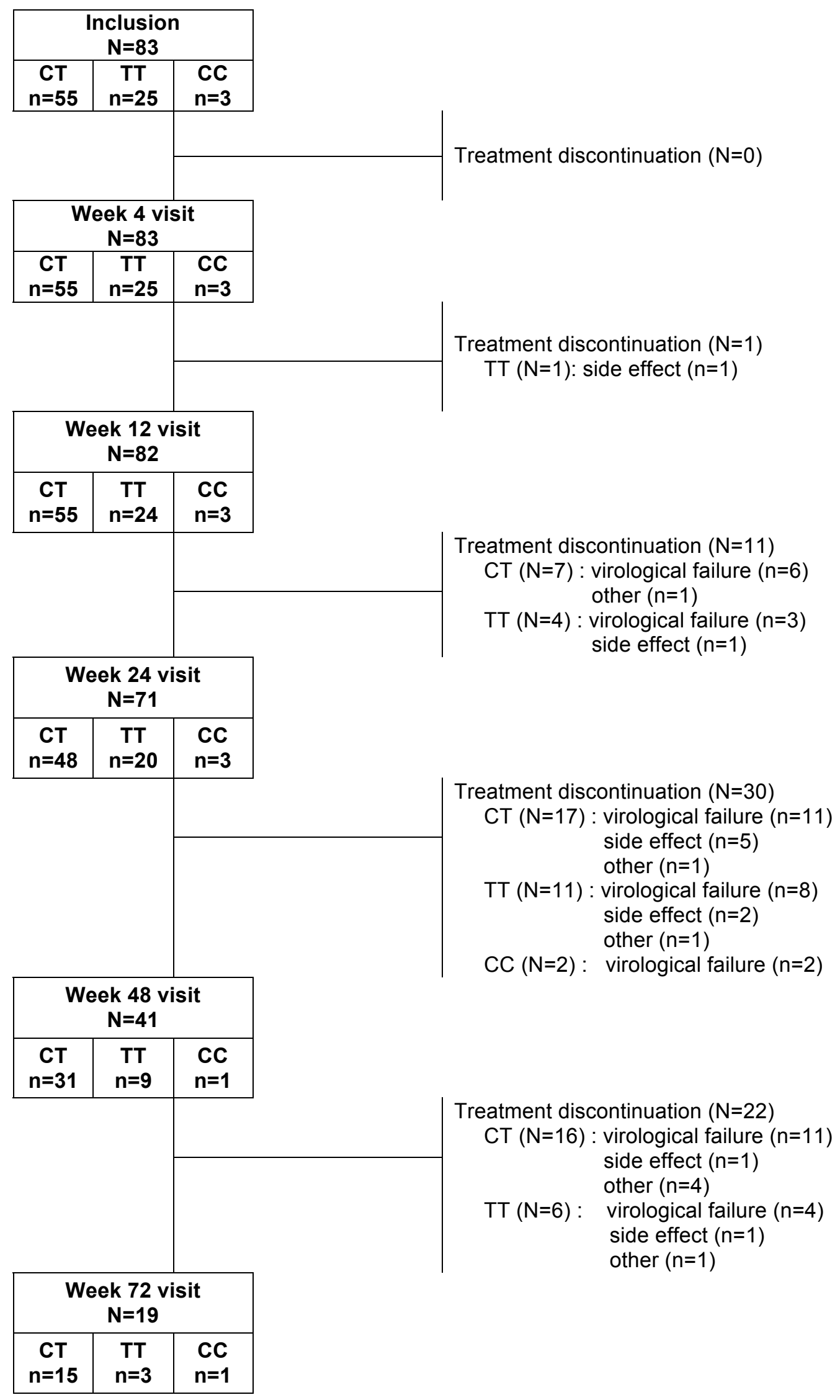




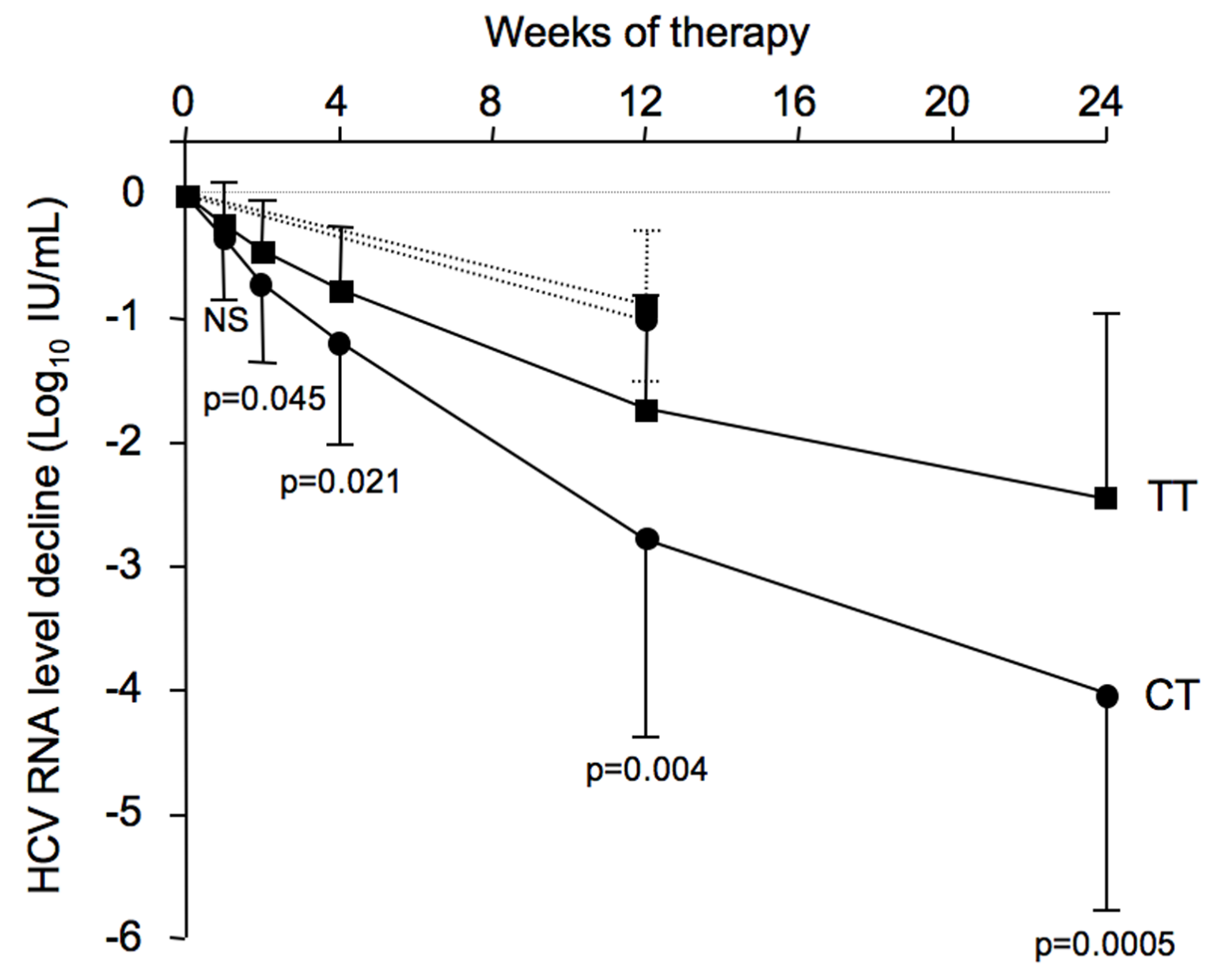

